\title{
ANALISIS PENGELOLAAN BARANG MILIK DAERAH di KABUPATEN MINAHASA UTARA (Studi Kasus Pada Badan Keuangan Kabupaten Minahasa Utara)
}

\author{
Conda Liesye Yolinita Dita Kalangi ${ }^{1}$, Lintje Kalangi ${ }^{2}$, Jessy D.L Warongan ${ }^{3}$ \\ 1,2,3 Jurusan Akuntansi, Fakultas Ekonomi dan Bisnis, Universitas Sam Ratulangi, Jl. Kampus Bahu, Manado, \\ 95115, Indonesia \\ E-mail : dhitakalangi@gmail.com
}

\begin{abstract}
Management of Regional Property is one of the important indicators in the preparation of financial statements, thus affecting the quality of Local Government Financial Report (LKPD). This study aims to determine the suitability of the management of Regional Property at the Finance Agency of North Minahasa District with the Regulation of the Minister of Home Affairs No. 17 of 2007. This study, the authors use the type of qualitative data from primary and secondary sources. Primary data is taken from place, which is done through obsevarsi and interview. And secondary data, data obtained from the documentation. From the research result shows that the Management of Regional Property in North Minahasa Regency in Budget Year 2015, has been in accordance with the Minister of Home Affairs Regulation No. 17 of 2007, and now has been referring to the Minister of Home Affairs Regulation No. 19 of 2016.

Key words : Management of Regional Property.
\end{abstract}

\section{PENDAHULUAN}

Dimana menurut Mardiasmo (2016 : 93) mengatakan bahwa, secara umum, aset pemerintah daerah adalah semua bentuk kekayaan atau sumber daya ekonomi yang dikuasai pemerintah daerah dan digunakan untuk mencapai tujuan penyelenggaraan pemerintah daerah. Kekayaan pemerintah daerah disimbolkan dalam neraca berupa aset, dan aset terdiri dari aset lancar, aset aset tetap, dan aset lainnya, Barang Milik Daerah termasuk dalam aset tetap.

Aset tetap menurut Peraturan Pemerintan Republik Indonesia Nomor 71 Tahun 2010 tentang Standar Akuntansi Pemerintah adalah aset berwujud yang mempunyai masa manfaat lebih dari 12 (dua belas) bulan untuk di gunakan, atau dimaksudkan untuk di gunakan, dalam kegiatan pemerintah atau dimanfaatkan oleh masyarakat umum. Aset tetap yang di maksud ialah berupa tanah, peralatan dan mesin, gedung dan bangunan, jalan, irigasi, dan jaringan, aset tetap lainnya dan kontruksi dalam pengerjaan. Berikut ini adalah klasifikasi aset tetap yang digunakan dalam Peraturan Pemerintah Republik Indonesia Nomor 71 Tahun 2010 tentang Standar Akuntansi Pemerintahan Penyataan Nomor 07 :

1. Tanah yang dikelompokkan sebagai aset tetap ialah tanah yang diperoleh dengan maksud untuk dipakai dalam kegiatan opersaional pemerintah dan dalam kondisi siap dipakai.

2. Peralatan dan Mesin mencakup mesin-mesin dan kendaraan bermotor, alat elektronik, dan seluruh inventaris kantor, dan perlatan lainnya yang nilai signifikan dan masa manfaatnya lebih dari 12 (dua belas) bulan dan dalam kondisi siap pakai.

3. Gedung dan Bangunan mencakup seluruh gedung dan bangunan yang diperoleh dengan maksud untuk diakai dalam kegiatan operasional pemerintah dan dalam kondisi siap dipakai. 
4. Jalan, Irigasi, dan Jaringan mencakup jalan, irigasi dan jaringan yang dibangun oleh pemerintah serta dimiliki dan/atau dikuasasi oleh pemerintah dan dalam kondisi siap pakai.

5. Aset tetap Lainnya mencakup aset tetap yang tidak dapat dikelompokan ke dalam kelompok aset tetap di atas, yang diperoleh dan dimanfaatkan untuk kegiatan operasioanal pemerintah dan dalam kondisi siap dipakai.

Barang Milik Daerah merupakan salah satu indikator penting dalam penyusunan laporan keuangan, sehingga mempengaruhi kualitas Laporan Keuangan Pemerintah Daerah (LKPD). Berdasarkan temuan BPK dari hasil Laporan Keuangan Pemerintah Kabupaten Minahasa Utara Tahun 2015 telah sesuai dengan Standar Akuntansi Pemerintahan (SAP) berbasis akrual, telah diungkapkan memadai. Dan pemeriksaan BPK menyimpulkan bahwa opini atas Laporan Keuangan Pemerintah Kabupaten Minahasa Utara Tahun 2015 adalah Wajar Tanpa Pengecualian (WTP). Namun Badan Pemerikasa Keuangan (BPK) masih menemukan permasalahan yang hendaknya masih memerlukan perhatian, yaitu pengeloaan barang milik daerah tidak tertib. Maka penulis tertarik untuk melakukan penelitian“Analisis pengelolaan barang milik daerah di Kabupaten Minahasa Utara (Studi kasus pada Badan Keuangan Kabupaten Minahasa Utara)".

\section{TINJAUAN PUSTAKA}

2.1. Akuntansi Pemerintahan

Pengertian akuntansi pemerintahan, pada hakekatnya akuntansi pemerintahan adalah aplikasi akuntansi di bidang keuangan Negara (public finance), khususnya pada tahapan pelaksanaan anggaran (budget execution), termasuk segala pengaruh yang ditimbulkannya, baik yang bersifat seketika maupun yang lebih permanen pada semua tingkatan dan unit pemerintahan. Menurut Revrisond Baswir (2000:7), akuntansi pemerintahan (termasuk akuntansi untuk lembaga non profit pada umumnya) merupakan bidang akuntansi yang berkaitan dengan lembaga pemerintahan dan lembaga-lembaga yang bertujuan untuk tidak mencari laba. Walaupun lembaga pemerintah senantiasa berukuran besar, namun sebagaimana dalam perusahaan ia tergolong sebagai lembaga mikro.

Bachtiar Arif dkk (2002:3) mendefinisikan akuntansi pemerintahan sebagai suatu aktivitas pemberian jasa untuk menyediakan informasi keuangan pemerintah berdasarkan proses pencatatan, pengklarifikasian, pengikhtisaran suatu transaksi keuangan pemerintah serta penafsiran atas informasi keuangan tersebut. Sedangkan menurut Abdul Halim (2002:143) menyebutkan bahwa Akuntansi Pemerintahan adalah sebuah kegiatan jasa dalam rangka menyediakan informasi kuantitatif terutama yang bersifat keuangan dari entitas pemerintah guna pengambilan keputusan ekonomi yang nalar dari pihak-pihak yang berkepentingan atas berbagai alternatif arah tindakan.

\subsection{Standar Akuntansi Pemerintah}

Standar Akuntansi Pemerintahan adalah salah satu aspek yang penting untuk meningkatkan kualitas tata kelola keuangan Negara/Daerah dan pelaporan keuangan pemerintah. Dan menurut Mahmudi (2011:271) menyatakan bahwa standar akuntansi pemerintah perlu dikembangkan untuk memperbaiki praktik akuntansi keuangan pada lingkungan organisasi pemerintahan.

\subsection{Standar Akuntansi Pemerintahan Berbasis Akrual}

Peraturan Pemerintah (PP) No.71 Tahun 2010 pasal 1 ayat (8) menyatakan bahwa standar akuntansi pemerintahan berbasis akrual adalah standar akuntansi pemeintahan yang mengakui pendapatan, beban, aset, utang dan ekuitas dalam pelaporan finansial, berbasis 
akrual, serta mengakui pendapatan, belanja dan pembiayaan dalam pelaporan pelaksanaan anggaran berdasarkan basis yang ditetapkan dalam APBN/APBD.

\subsection{Sistem Akuntansi Pemerintahan}

Berdasarkan PP 71 tahun 2010 Pasal 1 Sistem Akuntansi Pemerintah adalah rangkaian sistematik dan prosedur, penyelenggara, peralatan, dan elemen lain untuk mewujudkan fungsi akuntansi sejak realisasi transaksi sampai dengan pelaporan keuangan di lingkungan organisasi pemerintah. Yang dikutip oleh Saren (2016: 954) sebuah sistem akuntansi pada dasarnya terdiri atas input, yaitu berupa transaksi-transaksi keuangan, kemudian proses berupa analisis transaksi, jurnal, posting buku besar, yang kemudian akan menghasilkan output yaitu laporan keuangan.

\subsection{Pengelolaan Aset / Barang Milik Daerah}

Pengelolaan barang milik daerah dilaksanakan berdasarkan asas fungsional, fungsi kepastian hukum, transparansi dan keterbukaan, efisiensi, akuntanbilitas, dan kepastian nilai, dalam Peraturan Pemerintah Dalam Negeri Nomor 17 Tahun 2007 pasal 4 ayat (1).

Pada pasal 4 ayat (2) dalam Peraturan Dalan Negeri (Permendagri) pengelolaan barang milik daerah meliputi:

1. Perencanaan kebutuhan dan penganggaran;

2. Pengadaan;

3. Penerimaan, penyimpanan da penyaluran;

4. Penggunaan;

5. Penatausahaan;

6. Pemanfaatan;

7. Pengamanan dan pemeliharaan;

8. Penilaian;

9. Penghapusan;

10. Pemindahtanganan;

11. Pembinaan, pengawasann dan pengendalian;

12. pembiayaan; dan

13. tuntututan ganti rugi;

\subsection{Penelitian Terdahulu}

1. Penelitian yang dilakukan Monika (2015) berdasarkan hasil penelitian menunjukkan bahwa DPPKAD Kota Tomohon sebagai pembantu pengelola telah menerapkan 6 siklus dalam pengelolaan aset tetap. Dari 15 dokumen sumber yang diperlukan hanya ada 13 dokumen saja, sehingga pengelolaan aset tetap pada DPPKAD Kota Tomohon dengan Permendagri No.17 Tahun 2007 belum sepenuhnya sesuai.

2. Penelitian yang dilakukan Stenly (2016) berdasarkan hasil penelitian yaitu manajemen aset daerah di Kabupaten Kepulauan Siau Tagulandang dan Biaro merupakan bagian dari pengelolaan keuangan daerah yang mengacu pada peraturan perundang-undangan pemerintah. Perencanaan aset daerah mengacu pada kebutuhan dan pemeliharaan barang milik daerah sebagaimana berpedoman pada standarisasi sarana dan prasarana kerja pemerintahan daerah yang ditetapkan dengan Peraturan Kepala Daerah dan standar harga yang ditetapkan dengan Keputusan Kepala Daerah. Penghapusan aset daerah dari daftar aset pemerintah daerah dapat dilakukan jika aset tersebut sudah tidak memiliki nilai ekonomis, rusak berat, atau hilang. Saran yaitu perlu ada optimalisasi aset daerah yang ada dimana kebanyakan aset daerah masih berupa aset yang tidak dimanfaatkan. 


\section{METODE PENELITIAN}

\subsection{Jenis dan Sumber Data}

Dalam penelitian ini penulis menggunakan jenis data kualitatif dari sumber primer dan sumber sekunder, data kualitatif yang merupakan kumpulan dari data non-angka, yang bentuknya informasi baik lisan maupun tulisan, seperti: gambaran umum badan keuangan kabupaten minahasa utara, struktur orgnisasi, pembagian tugas, dan proses pengelolaan barang milik daerah.

\subsection{Metode Analisis Data}

Metode analisis data penulis mengambil dari Sugiono (2016:63) menyebutkan dalam penelitian kualitatif pengumpulan data dilakukan pada natural setting (kondisi yang alamiah), sumber data primer, dan teknik pengumpulan data lebih banyak pada observasi berperan (participant observation), wawancara mendalam (in depth interview) dan dokumentasi.

\section{HASIL ANALISIS DAN PEMBAHASAN}

\subsection{Hasil Analisis}

\section{Hasil Temuan Badan Pemeriksaan Keuangan}

Pengelolaan aset tetap pada Pemerintah Kabupaten Minahasa Utara jumlah dalam Neraca Laporan Keuangan per 31 Desember 2015 setelah penyusutan senilai Rp.990.483.636.155,03, dengan uraian sebagai berikut:

Tabel 4.2

\section{Rician Aset Tetap}

Sumber data Badan Keuangan Kabupaten Minahasa Utara

\begin{tabular}{|l|l|r|}
\hline No & \multicolumn{1}{|c|}{ Jenis Aset Tetap } & \multicolumn{1}{c|}{ Nilai (Rp) } \\
\hline 1 & Tanah & 235.868 .743 .851 .00 \\
\hline 2 & Peralatan dan Mesin & $220.962 .878 . .270 .40$ \\
\hline 3 & Gedung dan Bangunan & $286.123 .508 . .883 .35$ \\
\hline 4 & Jalan, Irigasi, dan Jaringan & 537.085 .068 .835 .87 \\
\hline 5 & Aset Tetap Lainnya & 20.133 .797 .573 .00 \\
\hline 6 & Konstruksi dalam Pengerjaan & 19.382 .756 .726 .40 \\
\hline 7 & Akumulasi Penyusutan & -329.073 .117 .984 .99 \\
\hline & JUMLAH & $\mathbf{9 9 0 . 4 8 3 . 6 3 6 . 1 5 5 . 0 3}$ \\
\hline
\end{tabular}

Dari hasil pemeriksaan Badan Pemeriksa Keuangan (BPK) Tahun Anggaran 2015 yang telah dilakukan, diketahui pengelolaan aset tetap di lingkungan Pemerintah Kabupaten Minahasa Utara belum tertib. Hal ini terlihat dari permasalahan yang ditemukan oleh Badan Pemeriksa Keuangan (BPK) Republik Indonesia, yaitu sebagai berikut.

1) Aset Tetap Tanah yang yang disajikan dalam Neraca Pemerintah Kabupaten Minahasa Utara Belum Didukung Bukti Kepemilikan

Pemkab Minahasa Utara telah memiliki daftar bukti-bukti kepemilikan atas tanah yang dikuasainya. Daftar bukti-bukti kepemilikan tersebut terdapat didalam Data Tanah Pemerintah Kabupaten Minahasa Utara. Dari hasil pemeriksaan yang telah dilakukan terhadap tanah yang dikuasai Pemkab Minahasa Utara diketahui terdapat aset tetap tanah sejumlah 31 bidang senilai Rp 13.413.890.160,00 yang tidak didukung dengan bukti-bukti kepemilikan tanah. Pemerintah Kabupaten Minahasa Utara telah berusaha untuk menginventarisasi dokumen kepemilikan tanah yang dimilikinya, namun atas sejumlah 31 bidang tanah tersebut, hingga saat pemeriksaan ini berakhir, belum diketahui keberadaan bukti pendukungnya.

Namun demikian, meskipun tidak ditemukan dokumen pendukungnnya, tanah-tanah tersebut telah dikuasai dan digunakan oleh Pemerintah Kabupaten Minahasa Utara, antara 
lain untuk bangunan kantor pemerintahan, rumah dinas, jalan komplek perkantoran, terminal, pusat kesehatan masyarakat, sekolah, dan lain-lain. Rician Daftar tanah tanpa dokumen bukti kepemilikan tersaji dalam Lampiran 1.

2) Bukti-bukti kepemilikan tanah yang dimiliki oleh Pemkab Minahasa Utara belum seluruhnya memadai.

Hak kepemilikan tanah didasarkan pada bukti kepemilikan tanah yang sah berupa sertifikat, misalnya Sertifikat Hak Milik (SHM), Sertifikat Hak Pakai (SHP), Sertifikat Hak Guna Bangunan (SHGB), dan Sertifikat Hak Pengelolaan (SPL). Sementara itu dari Minahasa Utara menunjukan bahwa dokumen-dokumen bukti yang ada ternyata bermacammacam, yaitu masing-masing hanya berupa sertifikat hak atas tanah, atau BA Pengukuran Tanah/Surat Ukur, atau Surat Keterangan Kepemilikan, atau Akta Jual Beli, atau Surat Pelepasan Hak, atau Surat Keterangan Hibah, maupun hanya Gambar Situasi. Dari hasil identifikasi terhadap Data Tanah, diketahui dari sejumlah 371 bidang tanah yang tercatat, jumlah bidang tanah yang didukung dokumen kepemilikan adalah sejumlah 340 bidang tanah dengan nilai tanah sebesar Rp 83.911.769.691,00. Dari jumlah tersebut, yang telah bersetifikat atas nama Pemerintah Kabupaten Minahasa Utara hanya sejumlah 60 bidang tanah senilai Rp 11.952.200.000,00. Dengan demikian masih terdapat 280 bidang tanah senilai Rp 71.949.569.691,00 yang bukti kepemilikannnyabelum memadai. Lampiran 2,3, dan 4.

Dari hasil pengujian secara sampel terhadap sejumlah 171 bukti-bukti kepemilikan tanah, diketahui sebagai berikut:

a). Dari 171 bukti kepemilikan tanah, bukti kepemilikan yang berhasil didentifikasi dalam daftar tanah adalah sejumlah 159 bidang tanah senilai Rp 19.376.589.801,00. Dari jumlah tersebut, terdapat 127 bidang tanah yang kepemlikannya atas nama Pemerintah Kabupaten Minahasa Utara, 24 bidang tanah yang kepemilikannya atas nama Desa, 2 bidang tanah yang kepemilikannya atas nama Dapertemen Pendidikan dan Kebudayaan, 4 bidang tanah yang kepemilikannya atas nama perorangan, dan 2 bidang tanah yang tidak jelas kepemilikannya. Lampiran 5.

b).Dari 127 bidang tanah atas nama Pemerintah Kabupaten Minahasa Utara, yang telah didukung dengan dokumen kepemilikan berupa sertifikat sejumlah 51 bidang tanah, sedangkan sisanya sejumlah 26 bidang tanah didukung dengan surat keterangan Hibah/Akta, 2 bidang tanah.

3) Pemkab Minahasa Utara tidak memiliki daftar bukti-bukti kepemilikan atas kendaraan bermotor yang update.

Dari hasil identifikasi terhadap pencatatan aset tetap berupa kendaraan bermotor diketahui Pemerintah Kabupaten Minahasa Utara memiliki kendaraan bermotor sejumlah 958 unit dengan nilai sebesar Rp 72.532.154.264,31. Berdasarkan data kendaraan bermotor yang tercatat dalam kartu inventaris barang, terdapat sejumlah 234 unit kendaraan bermotor senilai Rp 31.031.793.991,00 yang tidak teridentifikasi bukti kepemilikannya. Selain kartu inventaris barang, Pemkab Minahasa Utara juga memiliki daftar bukti-bukti kepemilikan atas kendaraan/alat angkutan yang dimiliki Pemkab Minahasa Utara, namun daftar BPKB tersebut belum update. Lampiran 6.

Jumlah kendaraan yang tercatat dalam daftar BPKB berbeda dengan jumlah kendaraan yang tercatat dalam Kartu Inventaris Barang (KIB). Daftar BPKB kendaraan dinas milik Pemerintah Kabupaten Minahasa Utara, mencatat jumlah kendaraan yang didukung dengan bukti kepemilikan berupa BPKB adalah sejumlah 368 kendaraan, sementara itu dalam kartu inventaris barang, jumlah kendaraan dinas yang tercatat didukung bukti kepemilikan adalah sebanyak 567 unit kendaraan bermotor. Dari hasil pemeriksaan fisik keberadaan kendaraan bermotor yang tidak teridentifikasi bukti kepemilikannya tersebut, masih ada dan digunakan untuk operasional Pemerintahan. 


\section{4) Pengamanan aset tetap peralatan dan mesin berupa barang inventaris kantor kurang memadai.}

Dari hasil pengamatan fisik yan telah dilakukan secara sampel pada Sekretariat Daerah, diketahui terhadap aset tetap peralatan dan mesin berupa barang inventaris kantor belum seluruhnya diidentifikasi dengan penempelan lebel kode barang. Penempelan lebel kode barang antara lain berfungsi untuk mengidentifikasi jenis/nama barang, lokasi barang, tahun pembelian, dan nomor registrasi barang yang sejenis. Dengan tidak adanya lebel kode barang yang tercatat dalam Kartu Inventaris Barang dikaitkan dengan keberadaan fisik barangnya.

\subsection{Pembahasan}

Berdasarkan analisis dan hasil penelitian yang diperoleh dari wawancara, obsevarsi dan dokumentasi, selanjutnya akan dilakukan atas temuan yang ada sesuai dengan teori/konsep yang mendukung hasl peneliian. Adapun hasil penelitian akan diuraikan sebagai berikut. Pengelolaan Barang Milik Daerah memiliki peran strategis sebagai salah satu indikator penting dalam pengelolaan keuangan daerah, untuk itu pengelolaan Barang Milik Daerah yang baik akan mencerminkan pengelolaan keuangan yang baik pula.

Pemkab Minahasa Utara telah memiliki daftar bukti-bukti kepemilikan tanah yang dikuasainya. Daftar bukti-bukti kepemilikan tersebut terdapat di Dalam Data Tanah Pemerintah Kabupaten Minahasa Utara. Dan dari hasil pemeriksaan BPK yang telah dilakukan terhadap tanah sejumlah 31 bidang senilai RP. 13.413.890.160,00 yang tidak di dukung dengan bukti-bukti kepemilikan. Dalam proses kepemilikan tanah di Pemkab Minahasa Utara berusaha menguhubungi ke register desa untuk membuat bukti kepemilikan tanah, dan setelah itu dari Pemkab membawanya pada Badan Pertanahan Nasional (BPN) yang berwewenang dalam membuat sertifikat tanah. Dan hambatan yang ditemukan dalam proses bukti kepemilikan pada BPN karena keterbatasan anggota yaitu Sumber DayaManusia (SDM).

Terhadap hasil wawancara, bahwa bukti kepemilikan di Pemkab Kabupaten pada saat ini sudah berjalan sesuai dengan Teknis Pedoman Pengelolaan Barang Milik Daerah PP Nomor 17 Tahun 2007. Dan sejauh ini Pemerintah Kabupaten Minahasa Utara telah berusaha untuk menginventarisasi dokumen kepemilikan tanah yang dimilikinya. Hak kepemilikan tanah didasarkan pada bukti kepemilikan tanah yang sah berupa Sertifikat Hak Milik (SHM), Sertifikat Hak Pakai (SHP), Sertifikat Hak Guna Bangunan (SHGB), dan Sertifikat Hak Pengelolaan (SPL). Sementara itu dari Pemkab Minahasa Utara menunjukan bahwa dokumen-dokumen bukti kepemilikan yang ada ternyata bermacam-macam, yaitu masingmasing hanya berupa Sertifikat ha katas tanah, BA Pengukuran Tanah/Surat Ukur, atau Surat Keterangan Hibah/Akta Hibah, maupun hanya gambar situasi.

Dari hasil identifikasi terhadap pencatatan aset tetap berupa kendaraan bermotor diketahui Pemerintah Kabupaten Minahasa Utara memiliki kendaraan bermotor sejumlah 958 unit dengan nilai sebesar Rp.72.532.154.264,31. Berdasarkan hasil wawancara mengenai aset tetap di Pemkab Minahasa Utara tidak memiliki daftar bukti-bukti kepemilikan atas kendaraan bermotor yang update karena, sebelun Tahun Anggaran 2015 setiap Dinas SKPD/PD yang memegang Surat kepemilikan kendaraan bermotor berupa BPKB.

Namun dari hasil peneriksaan fisik keberadaan kendaraan bermotor yang tidak didukung bukti kepemilikan sevara sampel menunjukkan kendaraan bermotor yang tidak teridentifikasi bukti kepemilikannya tersebut, masih ada dan digunakan untu operasional Pemerintah. Dan dari Pemkab melihat dari hasil temuan ini mengupayakan mengumpulkan surat kepemilikan atau BPKB motor pada Badan Keuangan di Bidang Aset.Penempelan lebel kode barang antara lain berfungsi untuk mengidentifikasi jenis/nama barang, lokasi barang, 
tahun pembelian dan nomor registrasi barang yang sejenis. Namun dari hasil observasi pada Pemkab Minut telah melebalkan setiap barang yang ada di setiap dinas Perangkat Daerah.

\subsubsection{Kesesuaian Pengelolaan Barang Milik Daerah di Kabupaten Minahasa Utara}

Sebagai salah satu unsur penting dalam penyelenggaran pemerintahan dan pelayanan kepada masyarakat, sangat penting bagi Pejabat Daerah untuk mengelola Barang Milik Daerah dengan sebaik mungkin. Untuk menunjang pengelolaan Barang MIlik Daerah agar menjadi lebih baik, sejak tahun tahun 2011 Pemerintah Kabupaten Minahasa Utara sudah mulai menggunakan Sisstem Informasi Barang Milik Daerah (SIMDA BMD) dalam penetausahaan aset tetap, untuk menyajikan data keuangan dan data fisik atas Barang Milik Daerah yang dicatat dan dilaporkan dalam neraca aset. Pengelolaan Barang Milik Daerah pada Pemerintah Kabupaten Minahasa Utara berdasarkan ruang lingkup Peraturan Menteri Dalam Negeri Nomor 17 Tahun 2007, sesuai dengan hasil penelitian dapat diuraikan sebagai berikut.

1. Perencanaan kebutuhan dan penganggaran;

2. Pengadaan;

3. Penerimaan, penyimpanan da penyaluran;

4. Penggunaan;

5. Penatausahaan;

6. Pemanfaatan;

7. Pengamanan dan pemeliharaan;

8. Penilaian;

9. Penghapusan;

10. Pemindahtanganan;

11. Pembinaan, pengawasann dan pengendalian;

12. pembiayaan; dan

13. tuntututan ganti rugi;

\section{KESIMPULAN DAN SARAN}

\subsection{Kesimpulan}

Berdasarkan hasil penelitian dan pembahasan yang ada maka peneliti menarik kesimpulan sebagai berikut:

1. Pengelolaan Barang Milik Daerah di Pemerintah Kabupaten Minahasa Utara pada tahun anggaran 2015 telah berjalan sesuai dengan Peraturan Menteri Dalam Negeri Nomor 17 Tahun 2007.

2. Pengelolaan Barang Milik Daerah di Pemerintah Kabupaten Minahasa Utara telah melaksanakan sesuai dengan 13 (tiga belas) siklus dalam Peraturan Menteri Dalam Negeri Nomor 17 Tahun 2007, dan sekarang telah mengacu pada Peraturan yang baru yaitu Peraturan Menteri Dalam Negeri Nomor 19 Tahun 2016.

\subsection{Saran}

1. Bagi pemerintah

Dari hasil temuan Badan Pemeriksaan Keuangan Republik Indonesia Tahun Anggaran 2015 bagi Badan Keuangan Pemerintah Kabupaten Minahasa Utara, saran saya:

a) Terhadap aset tetap tanah yang belum didukung bukti kepemilikan akan ditindaklanjuti dengan pembuatan sertifikat secara bertahap.

b) Harus ada dilaksanakan secara uji petik melalui pengecekan fisik kendaraan dengan pencocokan nomor mesin, rangka dan STNK dan memasukan BPKB. 
c) Kendaraan yang belum memiliki BPKB, harus diminta Surat Keterangan dari dealer yang bersangkutan.

d) Sumber Daya Manusia dari segi kuntitas harus adanya Penyimpanan Barang menjadikan tugas Pengurus Barang yang merangkap tidak maksimalkan dalam mengurus barang yang jumlahnya tidak sedikit sehingga barang yang berpindah tangan mudah hilang, rusak. Kemudian dari segi kualitas, ada beberapa diantara pengurus barang SKPD atau yang di sebut sekarang PD yang belum optimal penguasaannya dalam mengeoperasikan computer. Kemudian pengguna barang juga kurang memiliki pengetahuan dan pemahaman tentang pengelolaan barang milik daerah yang memadai sehingga implementasi kebijakan/ aturan dan prosedur pengelolaan Barang Milik Daerah belum optimal.

2. Bagi pihak lain

Disarankan bagi peneliti lain yang akan mengadakan penelitian lanjutan dari permasalahan dalam penelitian ini agar lebih kritis dalam membaca kondisi pengelolaan aset tetap dalam instansi-instansi pemerintahan.

\section{DAFTAR PUSTAKA}

Abdul Halim. 2002. Akuntansi Sektor Publik. Jakarta : Salemba Empat.

Kolinug, Monika Sutri. 2015. Analisis Pengelolaan Aset Tetap Pada Dinas Pendapatan Pengelolaan Keuangan Dan Aset Daerah Kota Tomohon. Jurnal EMBA FEB Unversitas Sam Ratulangi Manado. Vol. 3 No. 1 Maret 2015, Hal. 818-830. ISSN 2303-1174. Sulawesi Utara.

Peraturan Pemerintah Nomor 71 Tahun 2010 tentang Standar Akuntansi Pemerintahan Pernyataan Nomor 7 mengenai Akuntansi Aset Tetap.

Peraturan Menteri Dalam Negeri Nomor 17 Tahun 2007 tentang Pedoman Teknis Pengelolaan Barang Milik Daerah.

Permendagri Nomor 64 Tahun 2013 tentang Penerapan Standar Akuntansi Pemerintahan Berbasis Akrual.

Revrisond Baswir. 2000. Akuntansi Pemerintahan Indonesia. Yogyakarta: BPFE

Sugiono. 2016. Memahami Penelitian Kualitatif. Alfabeta. Bandung.

Tanjung, Abdul Hafiz. 2009. Penatausahaan dan Akuntansi Keuangan Daerah. Buku 2 (dua). Salemba Empat. Jakarta.

Tukunang, Stanly C.F. 2016. Manajemen Aset Daerah Pada Dinas Pendapatan Pengelolaan Keuangan Dan Aset Daerah Kabupaten Kepulauan Siau, Tagulandang, Biaro. Jurnal EMBA FEB Universitas Sam Ratulangi Manado.Vol.4 No.2 Juni 2016, Hal. 236-253. ISSN 2303-1734. Sulawesi Utara.

Undang-undang Nomor 22 Tahun 1999 tentang Pemerintah Daerah.

Undang-undang Nomor 32 Tahun 2004 tentang Pemerintah Daerah.

Undang-undang Nomor 23 Tahun 2014 tentang Pemerintah Daerah.

Undang-undang Nomor 25 Tahun 1999 tentang Perimbangan Keuangan antara Pemerintah Pusat dan Pemerintah Daerah.

Undang-undang Nomor 33 Tahun 2004 tentang Perimbangan Keuangan antara Pemerintah Pusat dan Pemerintah Daerah.

Undang-undang Nomor 23 Tahun 2014 tentang Perimbangan Keuangan antara Pemerintah Pusat dan Pemerintah Daerah. 